\title{
RACE, ETHNICITY, AND UNION IN THE CHICAGO STOCKYARDS, 1917-1922
}

Summary: This article examines the ways in which unionization impacted upon race relations in Chicago's meatpacking industry. It focuses upon a period when a dynamic working-class movement sought to overcome barriers imposed by a hierarchical job structure and reinforced by ethnic and racial divisions. The movement drew its strength from several sources. The support of the Chicago Federation of Labor threw the resources of a powerful local movement behind the campaign and encouraged the emergence of new, inclusive, forms of organization. The existence of shop-floor organizations further augmented the movement's power. Finally, the intervention of the government, in the form of binding arbitration, led to dramatic improvements in wages and conditions which helped the movement consolidate its position. Although these gains were undone and the movement destroyed, the union campaign transformed racial and class experiences in the stockyards.

\section{Introduction: The problem of race in American labor history}

"The problem of the twentieth century is the problem of the color-line", W.E.B. DuBois wrote in $1903 .{ }^{1}$ His words proved prophetic. In the United States, many of the major social and economic struggles of the past ninety years have centered upon the thorny question of the rights of black people and their relationship with the dominant white society. Throughout, the color-line has shown itself to be remarkably durable. Its particular form and shape have changed, but the deep fissure of race continues to define and animate American life.

The schisms produced by racial doctrines and practices have had their greatest impact upon the working class. Racial self-awareness has shaped the identity of American workers in a myriad of ways. It has influenced their politics and molded their consciousness. It has determined where they reside and under what conditions. It has been a crucial factor in establishing where they work, when they are laid off, and what kinds of opportunities for economic advancement are available to them. Most significantly, race has impacted upon workers' most important institutions - their trade unions. While differences of skill, ethnicity and gender have proved surmountable, the project of working-class organization has repeatedly foundered upon the shoals of racism. Despite episodic attempts to extend class

${ }^{1}$ W.E.B. DuBois, The Souls of Black Folk (New York, 1961), p. 23 (first edition: New York, 1903).

International Review of Social History, XXXVII (1992), pp. 25-58 
solidarity across racial lines, the labor movement has generally failed to include blacks in its conception of brotherhood. This failure has had longterm consequences. It hindered workers' ability to organize in the massproduction industries and weakened movements for reform. More decisively than other forms of fragmentation, race has contributed to the failure of organized labor to alter the trajectory of American capitalism.

Labor historians have only recently started to grapple with the difficult question of race and its implications for the study of the American working class. Despite the attention devoted by the "New Labor History" to issues of culture and consciousness, it has not produced a body of literature which addresses the interplay of class and race in a sustained manner. ${ }^{2}$ As David Roediger observes, the assumption remains "that the Black worker enters the story of American labor as an actor in a subplot which can be left on the cutting-room floor, probably without vitiating the main story". ${ }^{3}$

Part of this problem stems from an inadequate conceptualization of race both as an analytical term and as an historical category. Many scholars tend to regard "race" simply as a synonym for "black", to write about the working lives of African Americans as if they were hermetically sealed off from their white counterparts and exerted only minimal influence on the broader dynamics of working-class history. ${ }^{4}$ Race, like class, refers to a relationship between groups. John Cell's comments are instructive in this regard. "Only when racially conscious groups collide", he writes, "with the one rationalizing its dominance while the other strives to maintain its identity and integrity, does race become a social and historical factor". 5 Race occupies analytical space on both sides of the color-line; employed properly, it is a term that encompasses the interrelated experiences of both blacks and whites.

Other writers, particularly those concerned with documenting the labor movement's hostility towards non-whites, tend to consider race as a static historical category. This has led them to depict white racism as an immutable, constant factor in the working-class experience. ${ }^{6}$ Race and racial attitudes, on the contrary, are fluid, ever-changing historical products rooted

${ }^{2}$ Two recent studies hold out promise: Eric Arnesen, Waterfront Workers of New Orleans: Race, Class and Politics (New York, 1990), and Joe William Trotter, Jr., Coal, Class, and Color: Blacks in Southern West Virginia, 1915-1932 (Urbana, 1990).

${ }^{3}$ David Roediger, "'Labor in White Skin': Race and Working-class History", in Mike Davis and Michael Sprinker (eds), Reshaping the US Left (London, 1987), pp. 288-289.

${ }^{4}$ See, for example, Dennis Dickerson, Out of the Crucible: Black Steelworkers in Western Pennsylvania, 1875-1980 (Albany, 1986).

5 John W. Cell, The Highest Stage of White Supremacy: The Origins of Segregation in South Africa and the American South (New York, 1982), p. 17.

${ }^{6}$ See, for example, Herbert Hill, "Race, Ethnicity and Organized Labor: The Opposition to Affirmative Action", New Politics, 1 [new series] (Winter 1987), 2, pp. 31-32. 
in the specific power relations of particular societies. White attitudes towards blacks, and black feelings about white workers and their institutions, have fluctuated along a broad spectrum. The task confronting the student of race and society is to distinguish the factors which have produced a change in attitude and ideology from those which have sustained a particular conception. ${ }^{7}$

In recent years, historical sociologists and economic historians have adopted and refined a labor market approach to understanding workingclass racism. ${ }^{8}$ While this framework has helped scholars conceptualize the "anatomy" of a given workforce and develop transnational comparisons, it too is flawed. It tends to take white racism for granted, and assumes that unions automatically function as barriers to immigrant and black employment. Racism tends to be reduced to a type of rational "economic" resentment; and minority workers too often are deprived of historical agency and seen as passive victims. Even in the hands of sensitive practitioners, labor market theory minimizes contingency and fails to formulate historically specific definitions of racial and class identities. ${ }^{9}$

This case study seeks to show that white working-class prejudice does not necessarily lead to racial discrimination, and that trade unions can mediate racial and occupational tensions. It considers a period in the history of packinghouse unionism in Chicago when a dynamic working-class movement sought to overcome the barriers imposed by a hierarchical job structure and reinforced by divisions of ethnicity and race. ${ }^{10}$ This movement took the form of an alliance between different segments of the stockyards' polyglot workforce. Its strongest base of support lay with the Slavic workers who filled most of the industry's semiskilled jobs. By incorporating the remnants of the once powerful Amalgamated Meat Cutters (AMC), the

7 Cell, Highest Stage, p. 16; see also Barbara J. Fields, "Ideology and Race in American History", in J.M. Kousser and James McPherson (eds), Region, Race and Reconstruction: Essays in Honor of C. Vann Woodward (New York, 1982), pp. 143-178.

8 The studies contributing to this model are too numerous to cite individually. The most important are Harold Baron, "Racial Discrimination in Advanced Capitalism: A Theory of Nationalism and Division in the Labor Market", in Michael Edwards et al. (eds), Labor Market Segmentation (Lexington, 1973), pp. 202-231; and Edna Bonacich, "A Theory of Ethnic Antagonism: The Split Labor Market", American Sociological Review, 37 (October 1972), pp. 547-559.

${ }^{9}$ For development of this critique see Alexander Saxton, The Rise and Fall of the White Republic: Class Politics and Mass Culture in Nineteenth-Century America (London, 1990), pp. 6-8.

10 A full history of packinghouse unionism in Chicago focusing upon race is provided in Eric Brian Halpern, "'Black and White Unite and Fight': Race and Labor Meatpacking, 1904-1948”' (Ph.D., University of Pennsylvania, 1989); for a complementary study of other major meatpacking centers see Roger Horowitz, "The Path Not Taken: A Social History of Industrial Unionism in Meatpacking" (Ph.D., University of Wisconsin, Madison, 1990). 
movement also secured the allegiance of the predominantly Irish and German "butcher aristocracy". Most important, the movement established ties with African American workers who streamed into the packing industry in record numbers during this era.

The movement drew its strength from several sources. The support of the Chicago Federation of Labor (CFL) threw the resources of a powerful local movement behind the campaign and encouraged the emergence of new, inclusive, forms of organization that anticipated the industrial unionism of the 1930s. The existence of powerful shop floor organizations - especially on the critical killing floors, where blacks and whites labored alongside one another - further augmented the movement's power. Finally, the intervention of the federal government, in the form of binding arbitration, led to dramatic improvements in wages and working conditions which helped the movement consolidate its position in the stockyards.

Ultimately, these gains were undone and the movement destroyed, torn apart from within by internal factionalism and racial strife, and countered from without by the superior power and resources of the packing companies. This outcome, however, does not mean that the steps taken in the direction of interracial and interethnic solidarity were insignificant. In its insurgent phase, the union campaign transformed racial and class experiences in the stockyards. The packinghouse workers who sought to unite behind common economic interests grappled with a series of questions that remained open-ended and unresolved for the next forty years. Questions concerning the rights and relationships of white and black workers, the ways in which racial and class consciousness become intertwined, and the impact of unionization upon race relations molded workers' self-perceptions and defined the course of packinghouse unionism.

\section{The wartime context}

The balance of power in the stockyards shifted considerably with the outbreak of the First World War. The packers held the upper hand, but hostilities in Europe set new forces in motion that redefined the context of industrial relations. The war effectively shut off immigration from Europe, depriving the packing companies of the abundant pool of cheap labor from which they traditionally drew. Between 1914 and 1918, immigration to the United States dropped by eighty percent. ${ }^{11}$ This decline, coupled later with domestic conscription and enlistment, produced severe labor shortages throughout the industrial economy.

In meatpacking, the situation was especially acute as many workers

${ }^{11}$ Historical Statistics of the United States (Washington DC, 1975), p. 119. 
seized the opportunity to secure jobs in more attractive settings. Turnover rates in Chicago's packinghouses rose to dizzying heights: between 1917 and 1918, annual labor turnover in the industry stood at 334 percent. ${ }^{12}$ Employment on the assembly line at Western Electric or at the McCormick Harvester Works might not yield more pay than meatpacking, but the work itself was cleaner and often lighter.

For the packing companies, the labor shortage was particularly vexing since it cramped their operations just when the allure of enormous profits beckoned. Well before the United States entered the conflict, the packers were wrestling with large war shipments. As early as 1914, European demand for meat products had canning departments in Chicago humming with activity. ${ }^{13}$ To capitalize on increased foreign demand, the packers needed to keep their plants operating at full capacity. They did this by tapping an important new source of labor: the stream of black migrants who were arriving in Chicago in record numbers from the Deep South.

A crisis in the South's cotton culture set off the northward movement of African Americans known as the "Great Migration". The spread of the boll weevil, a series of disastrous floods, and plummeting agricultural prices combined to force sharecroppers and tenants off the land. Pulled north by the availability of industrial jobs, half a million blacks left the South between 1916 and 1920. Approximately 50,000 of these migrants found their way to Chicago. ${ }^{14}$ The packing companies played an active role in directing the migratory stream. Using labor agents, they offered free transportation and the promise of jobs to laborers agreeing to travel north. They also took out advertisements in the widely circulated Chicago Defender, and transferred blacks to Chicago from their southern branch houses. ${ }^{15}$

More important than labor agents or want ads were the letters sent by migrants to their friends and families back home. One man in Chicago wrote a friend in Alabama, "Now it is true that the (col.) men are making good. Never pay less than $\$ 3.00$ per day for (10) hours." Another recent arrival wrote, "I am well and thankful to say I am doing well. I work in Swifts packing Co., in the sausage department [...] We get $\$ 1.50$ a day [...] Tell your husband work is plentiful here and he wont have to loaf if he want

${ }^{12}$ James R. Barrett, "Work and Community in 'The Jungle': Chicago's Packinghouse Workers, 1894-1922" (Ph.D. University of Pittsburgh, 1981), p. 298.

${ }^{13}$ That year American meatpackers exported 30 million tons of canned beef, 31 million tons of fresh beef, and 183 million tons of bacon to the Allies and neutrals abroad; "Meat for the Multitudes" (special issue of the National Provisioner (4 July 1981)) vol. 1, pp. $138,147$.

${ }_{14}^{14}$ Allan Spear, Black Chicago: The Making of a Negro Ghetto (Chicago, 1967), pp. 132, 140; James R. Grossman, "A Dream Deferred: Black Migration to Chicago, 1916-1921" (Ph.D., University of California, Berkeley, 1982), p. 5.

is Grossman, "Dream Deferred", p. 24; Chicago Commission on Race Relations, The Negro in Chicago (Chicago, 1921), pp. 59-61. 
to work. $" 16$ In this manner, the migration generated and sustained its own momentum. The names Armour and Swift were already familiar to many southern blacks since these large packers operated branch facilities throughout the region. Now that their friends and relatives were employed by these same companies, northern meatpacking figured prominently in their imaginations. "The packinghouses in Chicago for awhile seemed to be everything. You could not rest in your bed at night for Chicago", recalled one migrant. ${ }^{17}$

The children of sharecroppers, these workers' lack of education and job skills were no barrier to employment in an industry that depended heavily on unskilled labor. The transition from rural agricultural work rhythms to an urban industrial setting could be difficult to negotiate, but the monetary rewards helped ease the way. The contrast between wages in Chicago and those in the South was enormous. To a former cropper or tenant farmer unaccustomed to seeing currency and knowing only an increasing burden of debt, the prospect of a regular weekly paycheck of twelve dollars or more must have seemed too good to be true. Even experienced industrial laborers from the South often realized dramatic increases in income. ${ }^{18}$

In the short run, reliance upon black labor allowed the packing companies to increase production and reap record profits. ${ }^{19}$ In the long run, the turn to black labor affected far more than the packers' balance sheets: It led to a dramatic recomposition of the workforce and decisively shaped the form and character of organized labor's response to the wartime context.

The most pronounced change in the labor force was its sheer increase in size. During the war years, employment in Chicago's packinghouses almost doubled. ${ }^{20}$ Beneath this expansion lay a demographic shift, the most impor-

${ }^{16}$ Emmett J. Scott, "Letters of Negro Migrants of 1916-1918", Journal of Negro History, 4 (October 1919), pp. 464, 457, both quoted in Spear, Black Chicago, p. 133.

17 Quoted in Grossman, "Dream Deferred", p. 6.

${ }^{18}$ On the "breathtaking" contrast between northern and southern wages see David Montgomery, The Fall of the House of Labor: The Workplace, The State, and American Labor Activism (New York, 1987), pp. 383-384; Testimony of Joe Hodges, in Hearings of Judge Samuel Alschuler, 20-23 June 1919, in Records of the Federal Mediation and Conciliation Service, National Archives Record Center, Suitland Maryland (RG 280), 33/864 (hereafter cited as Alschuler Hearings).

19 "Meat for the Multitudes", pp. 138, 147; Philip Foner and Reinhard Schultz, Das Andere Amerika: Geschichte, Kunst, und Kultur der Amerikanischen Arbeiterbewegung (Berlin, 1983), p. 224. James Barrett reports that the four largest packers, which had shown an aggregate profit of 19 million dollars for 1912-1914, registered 46 million dollars for 1916 and 68 million dollars for the following year; James R. Barrett, Work and Community in the Jungle: Chicago's Packinghouse Workers, 1894-1922 (Urbana, 1987), p. 189.

${ }_{20}$ In 1914 , thirty-seven establishments utilized 26,408 workers. In 1919 , before demobilization had taken its toll, 45,695 packinghouse workers earned a living in Chicago's forty-six plants; Alma Herbst, The Negro in the Slaughtering and Meat-Packing Industry (New York, 1932), p. 151. 
tant contour of which was a climb in the proportion of blacks from three to twenty-five percent of the labor force. Indeed, the meatpacking industry was probably the single most important source of employment for blacks in Chicago. One source estimates that by the end of the decade one out of every two black men who held jobs in manufacturing was employed in the stockyards. ${ }^{21}$

If the war offered the packers the chance to fill their coffers with profits, it also provided labor with a fresh opportunity to organize workers in the stockyards. The labor shortage and the employers' need of full production created the most favorable climate in well over a decade. Unrest flared throughout the industry as workers tested their newly enhanced power. Settlement House worker Mary McDowell, always attentive to developments in the yards, noted that "when the workers, mostly Poles, Slovaks, and Lithuanians, became conscious of the undersupply of labor they grew restless. In separate departments there were constantly sporadic, unorganized strikes." 22

Something of the spontaneous nature of these job actions can be gleaned from Arthur Kampfert's account of his activities. In the spring of 1916, Kampfert led a stoppage in the Sulzberger \& Sons pork-trimming department aimed at securing a five-cent-an-hour increase. The strike quickly spread to the adjacent offal and casing departments. Workers met hurriedly and elected a bargaining committee which succeeded in negotiating a four-cent raise. Management, however, tempered the victory by discharging the leaders, including Kampfert. With labor in high demand, though, he had little difficulty finding employment at one of the smaller plants in the yards. A month later, he was at the center of another work stoppage. This one spread to the killing floor, effectively shutting down the entire plant. After three hours, management gave in and announced a general five-cent wage hike. Word of the victory spread, unleashing a wave of strikes throughout the yards. ${ }^{23}$

Conducted without benefit of formal union leadership, these sorts of stoppages occurred at a frenzied pace throughout 1916 and 1917. Although they succeeded in pushing up wages and securing minor improvements in

${ }^{21}$ Sterling Spero and Abram Harris, The Black Worker: The Negro and the Labor Movement (Port Washington, 1966) (first edition, 1931), p. 151. George Haynes, The Negro at Work During the World War and Reconstruction (Washington DC, 1921), pp. 52-56. Walter Fogel, The Negro in the Meat Industry (Philadelphia, 1970), p. 29.

2 "In the Stockyards District 1917", Mary McDowell Papers, Folder 15, Chicago Historical Society, Chicago IL; David Brody, The Butcher Workmen: A Study of Unionization (Cambridge, MA, 1964), p. 73.

${ }^{23}$ Arthur Kampfert, "History of Meatpacking, Slaughtering, and Unionism", II, pp. 97-100, unpublished manuscript (c. 1949), State Historical Society of Wisconsin, Madison, WI. 
working conditions, the absence of any overall coordination limited their effectiveness. Confined to one or two departments, job actions in this period were oriented around narrow goals and depended upon the initiatives of a few rank-and-file militants rather than mass organization of workers. Nevertheless, their frequency and the way in which they spread and involved other workers demonstrated the existence of considerable pro-union sentiment in the packinghouses.

Clearly, the stockyards were ripe for organization. The Amalgamated, however, was slow in responding to the challenge. Hobbled by internal factionalism and perpetually uncertain about the desirability of re-entering the packinghouses ever since their resounding defeat there in 1904, the Amalgamated stalled. In Chicago and elsewhere, packinghouse workers refused to wait. The stoppages continued unabated. Business, complained one industry executive, "cannot be conducted in an orderly manner [...] in this age of unrest". In the summer of 1916, major strikes idled thousands of workers in Sioux City and East St. Louis, but the AMC continued to equivocate. ${ }^{24}$

\section{The stockyards labor council}

While the AMC chose to ignore the ferment occurring in the packinghouses, other elements within the local labor movement did not overlook the unrest. The kinds of stoppages and job actions led by men like Kampfert attracted the attention of a small but influential group of labor radicals who, in the summer of 1917, persuaded the Chicago Federation of Labor to sponsor a campaign in the stockyards.

The idea of a formal organizing drive originated with William $Z$. Foster, working at the time as a railroad car inspector in the yards. Foster had built a solid base of support within the Chicago District Council of Railway Carmen, and used this body to advance his plan. In July 1917, he and a committee of Carmen approached a nearly defunct local of the Butcher Workmen and gained its reluctant endorsement of a resolution calling for a conference of all unions with jurisdiction over workers in the stockyards "for the purpose of launching and carrying on a united and vigorous campaign to bring within the protecting ranks of Organized Labor the vast army of men, women, and children in the meat packing industries of Chicago". The CFL passed the resolution unanimously and established the Stockyards Labor Council (SLC) on 23 July $1917 . .^{25}$

${ }^{24}$ Brody, Butcher Workmen, p. 73; National Provisioner, 14 October 1917, quoted in Brody.

${ }^{25}$ William Z. Foster, American Trade Unionism: Principles and Organization, Strategy 
The Stockyards Labor Council bore the unmistakable imprint of the syndicalists who had been working with Foster within the CFL since the early 1910s. Choosing to "bore from within" existing unions rather than establish independent ones of their own, Foster and his comrades had established a visible presence within Chicago's labor movement by 1917 . The defining characteristic of their activities was an effort to promote organizations that crossed the narrow lines of craft jurisdiction, skill, and union bureaucracy. Their greatest success came in the early 1910s when they succeeded in forming a Chicago Railroad District Council made up of locals of all rail unions. Despite bitter opposition on the part of the established railroad brotherhoods, the council idea spread throughout the country. ${ }^{26}$

In many regards, the SLC was modeled after the railroad council. Over a dozen unions with jurisdiction in the yards were represented. Locked together under a single executive board, the component unions hoped to form a solid front. With a set of organizers affiliated directly with the Council, the problems of internecine rivalries and competing jurisdictional claims could be bypassed. ${ }^{27}$

Working alone, Foster and his comrades could never have made the SLC a reality. Although their leadership was respected by many rank-and-file workers, and despite their circumspect approach to politics, the radicals did not enjoy warm relations with the city's craft unions. Only by enlisting the active support of the Chicago Federation of Labor was the creation of the SLC possible.

The CFL in 1917 was unlike any other labor council in the country. Under the leadership of John Fitzpatrick, the CFL advanced a militant, classconscious style of unionism that, in one historian's words, allowed Chicago to "challenge London for the title of trade union capital of the world". In addition to overseeing mass-organizing drives in meatpacking and steel during the 1917-1919 era, the CFL launched a Labor Party, supported the effort to unionize female teachers and clerical workers, and played a leading role in the movement to free Tom Mooney. Fitzpatrick welcomed progressives into the CFL, putting their talents to use in local campaigns. Edward Nockels, the CFL's secretary, headed a group of mainstream activists that included Margaret Haley of the teachers' union and socialist carpenter Anton Johannsen. The most cohesive grouping of radicals, however, were the hundred or so syndicalists associated with Foster's In-

and Tactics (New York, 1947), p. 22; Edward Johanningsmeier, “William Z Foster: Labor Organizer and Communist" (Ph.D., University of Pennsylvania, 1988), chapter 5. See also William Z. Foster, "How Life Has Been Brought into the Stockyards", Life and Labor, 7 (April 1918), p. 64.

26 Johanningsmeier, "William Z. Foster", chapter 5.

${ }^{27}$ Foster, American Trade Unionism, p. 22. 
ternational Trade Union Educational League. Fitzpatrick, committed to industrial unionism, was able to work comfortably with these activists. ${ }^{28}$

The endorsement of the CFL and Fitzpatrick's personal involvement were instrumental in securing the support of the constituent unions which made up the Stockyards Labour Council. The Federation also agreed to pay the initial expenses of the SLC's organizers and to finance the first mass meeting. Most important, the CFL's sponsorship of the stockyards campaign allowed radicals like Foster and J.W. Johnstone to play leading roles in the day-to-day formulation of strategy and tactics. Their presence acted as a counterweight against the conservative tendencies of the craft unionists. This became especially clear over the course of the next two years in two areas of vital importance: the movement's relationship to black workers and the SLC's response to government arbitration.

The drive began slowly, with more than a month spent laying the groundwork for the campaign: ironing out logistical problems, assembling an organizing staff, and establishing contact with rank-and-file activists. On 9 September, the first mass meeting attracted 10,000 workers. However, the results were meager. Although the assembled crowd warmly received the speakers, the call for signing up was met by "a dull silence for a moment then many of those in attendance began to slip away". Only a handful of individuals came forward and joined. Although packinghouse workers were anxious for action, an awareness of spies and a well-founded fear of company reprisals compelled them to remain aloof. The fact that Amalgamated officials shared the platform did little to inspire confidence. Workers remembered the 1904 disaster and, in Foster's words, the "long years of AFL betrayal and incompetence" in the meatpacking industry. ${ }^{29}$

By November, however, the drive had gathered considerable momentum. The SLC's submission of a list of specific demands, including substantial wage increases, equal pay for women, and an eight-hour day, generated enthusiasm and sparked an influx of workers into the union. Especially encouraging was the response among the foreign-born. In the space of a single month, more than ten thousand Poles and Lithuanians poured into Local 554, reserved for Slavic laborers. The native skilled workers proved more difficult to organize, but by December they had come around. At the year's end the SLC, while still facing an uphill battle, had gained a solid foothold..$^{30}$

${ }^{28}$ Montgomery, Fall of the House of Labor, p. 269; Barrett, Work and Community, pp. 191-192; Johanningsmeier, "William Z. Foster", chapter 5; Foster, American Trade Unionism, pp. 20-21. For the career and trade-union philosophy of Fitzpatrick see John Keiser, "John Fitzpatrick and Progressive Unionism" (Ph.D., Northwestern University, 1965).

${ }_{29}$ Johanningsmeier, "William Z. Foster”, chapter 5; Brody, Butcher Workmen, p. 76; Barrett, Work and Community, p. 195. 
While the packing companies mulled over the SLC's demands, organizing continued. The greatest challenge facing the union was reaching out to the 12,000 blacks laboring in the stockyards. While close to ninety percent of the white workers had entered the union fold, most blacks kept their distance. ${ }^{31}$ Organization of these workers was imperative if the SLC hoped to stand up to the power of the packing companies; yet several formidable obstacles had to be cleared away before this could be accomplished.

The most immediate problem was where to place black workers once they were organized. Most of the craft unions in the SLC barred blacks from membership by constitutional decree. The Machinists, for instance, limited membership to "white, free born male citizens of some civilized country", and Foster's own Brotherhood of Railway Carmen specified that only "a white person, male or female, of good moral character" could join. The real issue, of course, was much larger than these legalisms. How far did the institutional racism of the unions extend? Were they willing to abandon Jim Crow in order to demonstrate their good will toward black workers? Opinion was divided. In a quandary, SLC leaders secured permission to enroll blacks excluded from the craft unions into separate "federal" locals affiliated directly with the American Federation of Labor. ${ }^{32}$

This compromise was a poor solution. Federal locals segregated blacks from whites and hindered the building of interracial solidarity. This was made clear by the more pressing problem of where to place the much larger mass of black packinghouse workers. Initially, SLC leaders planned to enroll these workers directly into locals of the Amalgamated Meat Cutters, which drew no color line and had accepted blacks into their ranks in the past. Within a short time, however, blacks began to protest their minority status in these locals. Whether these complaints originated with black leaders influenced by the packing companies, as Foster later suggested, or whether they were bona fide concerns raised by workers is unknown. In response, the SLC established two all-black locals, 651 for men and 213 for women. Predictably, this move exposed the SLC to accusations of fostering segregation. "Almost overnight", Foster recalled, "the cry of 'Jim Crow' went along State Street with devastating effect." 33

Anxious to deflect this criticism, an agreement was worked out whereby

${ }^{30}$ Barrett, Work and Community, p. 195; Brody, Butcher Workmen, pp. 76-78; Foster, American Trade Unionism, p. 25.

${ }^{31}$ Herbst, Negro, p. 29.

${ }^{32}$ Constitutions quoted in Herbert Hill, "Race and Ethnicity in Organized Labor: The Historical Sources of Resistance to Affirmative Action", Journal of Intergroup Relations, 12 (Winter 1984), p. 22. Herbst, Negro, p. 31; William M. Tuttle, Jr., Race Riot: Chicago in the Red Summer of 1919 (New York, 1970), p. 125.

${ }^{33}$ Herbst, Negro, p. 32; Barrett, Work and Community, p. 194; Foster, American Trade Unionism, pp. 22-23; see also Foster's The Great Steel Strike (New York, 1920), p. 211. 
the mass Amalgamated locals composed of laborers would be established on a community basis, with membership being interchangeable among them. The decision to create community-based locals had the unfortunate effect of furthering de facto segregation, deflecting rather than resolving the racial dilemma. Alma Herbst accurately terms this move a "sincere, albeit calculating gesture from organized labor. Necessity demanded that recognition be given to the strength of the Negro group; expediency dictated the membership policy". ${ }^{34}$

Regardless of intent, the tortured maneuvering of the SLC around the race issue raised black suspicions. The hiring of additional black organizers and the election of A.K. Foote, a black hog butcher, as vice-president of the Labor Council, only partially allayed fears that the "white man's union" was up to its old tricks. At the end of 1917, the SLC's efforts to organize black workers had yielded disappointing results. While a good proportion of northern-born blacks responded to the union's appeal, little progress was made among the thousands of southern migrants working in the stockyards. "If we were dealing with what we call the northern negro, we should not have very much difficulty", Fitzpatrick lamented in December. "They understand the necessity of organization ... but the southern negro is different. We figure that his slavery days ended at about the time that he came up here to work in the Packing houses.",35

Part of the difficulty in recruiting blacks lay in the fact that most southerners only dimly understood the concept of unionism. Irene Goins, a black female organizer, reported "my people know so little about organized labor that they have had a great fear of it, and for that reason the work of organizing has proceeded more slowly than I anticipated". Others echoed her remarks. Simple ignorance, the paternalism of the packers, and the dramatic contrast between conditions in Chicago and those in the rural South frustrated efforts to win the support of black workers. Mary McDowell illustrated the point with a story about a black man approached on the job by a union delegation. After listening intently to their appeal he asked, "It all sounds pretty good to me, but what does Mr. Armour think about it?"36

Moreover, many blacks who were familiar with unions had a negative

${ }^{34}$ Herbst, Negro, pp. 32-33.

${ }^{35}$ Earl Browder, "Some Experiences Organizing Negro Workers", The Communist, 9 (1930), pp. 35-41. Foote is identified in Carl Sandburg, The Chicago Race Riot: July 1919 (New York, 1919), p. 54. For the response of northern blacks see Grossman, "A Dream Deferred", p. 306; and Edna Louise Clark, "A History of the Controversy Between Labor and Capital in the Slaughtering and Meat Packing Industries in Chicago" (MA Thesis, University of Chicago, 1922), p. 106. Fitzpatrick quoted in Herbst, Negro, pp. 36-37.

${ }_{36}$ Goins quoted in Tuttle, Race Riot, p. 127; McDowell quoted in Spero and Harris, The Black Worker, p. 130. 
view of them. "Unions ain't no good for a colored man. I've seen too much of what they don't do for him", remarked one worker. The labor movement's history of racial exclusion now haunted the SLC's efforts to forge a new path. Lowell Washington, who had moved to Chicago in 1915 from Mississippi, refused to have anything to do with the Stockyards Labor Council. Soon after settling in Chicago he had sought work as a bricklayer, a trade he had performed for fifteen years in Vicksburg. White union members not only denied him credentials but verbally and physically assaulted him for his "upitiness". Resigned and bitter he took a job in the yards, earning money to bring his family north. When union organizers approached him at the beginning of the campaign, he "turned his back on them, just wouldn't have nothing to do with them, wouldn't listen to those white men and wouldn't talk to them neither". Countless other blacks experienced similar rebuffs. The perception that unions operated to benefit whites at blacks' expense was widespread and not easily shaken. ${ }^{37}$

Despite SLC efforts to forge ties with the black community, sentiment there towards the union campaign was ambivalent at best, and unremittingly hostile at worst. The most important institution, the black church, actively opposed the cause. Methodist bishop Archibald Carey expressed the dominant view of the religious establishment when he declared, "the interests of my people lies with the wealth of the nation and the class of white people who control it". A number of black churches received generous contributions from the packing companies and were unwilling to endanger this support by giving sanction to a union drive which had yet to prove its integrity and intentions. Still, the church did not close ranks on the issue. Reverend Lacey Kirk Williams of the large Olivet Baptist Church and a few other ministers offered limited support, even while warning against unspecified radical elements. Hoping to sway some of the more religious black workers, the SLC secured a representative from the Baptist Ministers' Alliance to address meetings, and even hired a preacher, G.W. Reed, as a part-time organizer. ${ }^{38}$

Winning the approval of the black press was no easy task; even its qualified support was difficult to gain. The leading newspaper, the Chicago Defender, vacillated throughout the organizing campaign. It virtually ignored the start of the drive; and when it did take notice, counseled its readers to exercise utmost caution in dealing with the union. Aware of the importance of packinghouse employment to blacks, there were times when the Defender seemed to side with the packing companies. A 1918 article

37 Chicago Commission on Race Relations, Negro in Chicago, p. 424. Interview with Lowell Washington, Jr., 28 April 1988, in possession of the author.

38 Grossman, “A Dream Deferred”, pp. 340-342; Sandburg, Chicago Race Riots, p. 57; Barrett, Work and Community, pp. 205, 213. 
proclaimed: "The name of Armour has always been a sign of justice, so far as our Race is concerned". Yet at other moments the paper supported the union effort - as when publisher Robert Abbott agreed to address workers on behalf of the SLC. The second largest paper, The Broad Axe, disregarded the union entirely, while the Advocate consistently opposed it at every turn. Only the small circulation Chicago Whip backed the drive and encouraged its readers to do the same. Although the Whip's enthusiasm later waned, it featured a regular column by John Riley, one of the black organizers at work in the stockyards. ${ }^{39}$

No one was more keenly aware of the black's resistance to unionism than the packing companies. Already heavily dependent upon black labor when the SLC drive began, the packers now increased their numbers in the workforce even further. During 1917-1918, the black labor force in Chicago's packinghouses jumped three to five times. ${ }^{40}$ This rise was a deliberate response to the success of the SLC in organizing white laborers. While the SLC was in its formative stages, Swift directed its branch plants to quietly begin discharging activists and replacing them with "colored help". Such policies could not be kept covert for long. Soon the packers were openly moving against the union and sowing seeds of racial discord. When a group of conveyance truckers struck at Armour, for instance, management promptly replaced them with blacks. In some departments, especially all-white ones, foremen threatened that if "we had anything to do with the union guys, then we'd find ourselves cleaning casings [a particularly disagreeable task] while the colored girls would be on our jobs". Such reprisals and threats occurred frequently, prompting the CFL to accuse the packers of fomenting racial friction and antagonism. ${ }^{41}$

The brewing conflict boiled over in late 1917 when Libby, McNeil \& Libby fired sixty unionists. By this time the movement had spread to other midwestern packing centers; SLC militants began to believe that momentum was on their side. Led by Foster, they seized upon this provocation and pressured the Amalgamated into taking a national strike vote. On Thanksgiving eve, packinghouse workers voted overwhelmingly to empower the leadership to call a nationwide walkout. At this juncture, however, labor leadership divided into opposing camps. Amalgamated officials, feeling bound to the wartime no-strike pledge and afraid of sharing authority with the Chicago radicals, opposed taking action. In their view, the vote

39 Grossman, “A Dream Deferred”, pp. 345-346, 351-352; Chicago Defender, 6 July 1918, quoted in Tuttle, Race Riot, p. 153; Barrett, Work and Community, p. 205.

Tuttle, Race Riot, pp. 128-129, fn. 39.

41 The Swift correspondence first was cited in Clark, "A History", p. 102, and is quoted at length in Herbst, Negro, pp. 33-44; Interview with Gertie Kamarczyk, 5 December 1987, in possession of the author. See also, Tuttle, Race Riot, p. 129; and Kampfert, "History", II, pp. 105-106. 
simply served to strengthen their hand. Fitzpatrick, too, felt that a walkout would be premature and jeopardize their gains. On the other hand, Foster and Johnstone wanted to press forward with the strike, believing it the only way to induce the packing companies to sign an agreement with the union..$^{42}$

This was the first open manifestation of internal tensions present within the SLC from the start. Amalgamated officials distrusted Foster's group, even though their boldness and initiative had revived the AMC's sagging fortunes. They complained about the power exercised by Foster's comrades who, in their view, had injected themselves into a movement to which they had only a tenuous connection. The Amalgamated's Dennis Lane later assailed Johnstone and his "small band of IWW's from the Northwest" who "blew into Chicago" shortly before the start of the stockyards campaign. In addition, AMC leaders resented the way in which the SLC dominated the process of preparing negotiating positions and formulating overall policy. These were matters best left to the constituent unions; the heavy handed role played by Foster and Johnstone caused them to chafe. For their part, the radicals felt that the Amalgamated remained too firmly wedded to an outmoded craft union conception of organization and lacked sufficient backbone to face down the packing companies. Foster accused "reactionary" Amalgamated officials of reneging on their promise of financial support and opposing the "militant line" favored by both SLC leaders and rank-and-file organizers. ${ }^{43}$

The question of whether a strike could have been won in the winter of 1917 soon became moot. Before the conflict over strike policy could play itself out, a new player entered the game. In December 1917 the federal government intervened in the dispute. Fearing that a strike would disrupt essential production, Secretary of War Newton Baker ordered a mediation commission to defuse the situation. After several weeks of wrangling, an accord was reached. On Christmas Day, the packers and the unions signed an agreement prohibiting strikes and lockouts for the duration of the war. A government administrator would impose binding arbitration where negotiation failed to settle grievances. ${ }^{44}$

While the AFL unions embraced government arbitration, Fitzpatrick, Foster, and Johnstone harbored deep reservations. To start with, the agreement did not call for union recognition and was not a substitute for a contract. The radicals feared it would demobilize the organizing campaign. Moreover, earlier attempts at arbitration had failed when intransigent

${ }^{42}$ Foster, American Trade Unionism, p. 26; Brody, Butcher Workmen, pp. 78-79; Johanningsmeier, "William Z. Foster", chapter 5.

${ }^{43}$ Dennis Lane, "A Brief History of Organization in Chicago Stock Yards", Butcher Workman (November 1919), p. 1; William Z. Foster, From Bryan to Stalin (New York, 1936), pp. 90-93; see also Foster, American Trade Unionism, pp. 25-27.

44 Brody, Butcher Workmen, pp. 79-80. 
employers defied government mediators and refused to accede to elementary union demands. In such cases, Foster argued, "workers naturally conclude that if the Government can do nothing with their autocratic employers it is useless for them to keep up the fight". ${ }^{45}$ If government intervention had prevented a strike, it failed to resolve the conflict between labor and capital. When arbitration expired at the war's end, the struggle would begin where it had left off. Similarly, if the entry of the government precluded an open split within the union ranks, it did little to reduce the tensions between radicals guiding the SLC and more cautious trade unionists.

Their reservations notwithstanding, both Foster and Johnstone played an active role in the first round of arbitration. Throughout February 1918, Judge Samuel Alschuler listened to testimony offered by packinghouse workers, their wives, and children. Representatives of the packers, social workers, and economists testified as well, but the spotlight was fixed upon ordinary workers. "It was as if the characters in The Jungle, quickened into life, had come to tell their story from the witness chair", Foster wrote. Frank Walsh, the former director of the US Commission on Industrial Relations, represented the union. In a brilliant performance, he not only established the justice of the union's demands but persuasively demonstrated the packers' ability to meet the increased costs. The hearings received considerable media attention. One typical headline screamed "Life's hardships told by women of stockyards: One lived in Chicago six years, never saw movie, park, nor Lake Michigan". Attorneys for the packing companies attempted to defend their labor practices, but the evidence overwhelmed their arguments and mocked their efforts to paint a picture of corporate benevolence. ${ }^{46}$

Three weeks after the hearings closed, Judge Alschuler announced his decision. Hailed by Arthur Kampfert as "the Magna Carta for packinghouse workers", the award granted the eight-hour day, a guaranteed 48hour week, time and a quarter for overtime, the full dollar-a-week raise demanded by the union, a proportional increase for all piece-rate workers, and equal pay for men and women. ${ }^{47}$ The reaction in Packingtown was celebratory. A large crowd assembled for a rally in Davis Park, directly across from the packing plants. "It's a new day", Fitzpatrick proclaimed to the interracial gathering. "Out in God's sunshine, you men and you women, black and white, have not only an eight hour day but you are on an equality". A sense of the hope and optimism which animated workers is

${ }^{45}$ Foster, From Bryan to Stalin, p. 97.

${ }^{46}$ Foster, "How Life", p. 68; Brody, Butcher Workmen, pp. 81-82; Barrett, Work and Community, pp. 198-200.

${ }^{77}$ Kampfert, "History", II, p. 132; Barrett, Work and Community, p. 200. Bureau of Labor Statistics, Monthly Review, 6 (May 1918), pp. 115-127. 
conveyed in their christening a row of park benches "Eight Hour Benches". Before Alschuler's award, workers had no leisure time in which to lounge in the park. Now, they could sit with their children and enjoy the sun. ${ }^{48}$

The arbitration decision boosted the union cause. Throughout the Spring of 1918 holdouts poured in. Ida Glatt, an officer of the Women's Trade Union League, anticipated one hundred percent organization in the near future. The union's secretaries, she reported, "do nothing but take in applications from morning to midnight". In a ten-month period the Amalgamated reported a doubling of its membership. Even the normally pessimistic Foster sounded a bright note, writing to Walsh: "We are doing well here in the Yards. The organizations maintain themselves very good, in spite of the croakers who said they would fall to pieces as soon as the excitement died out. I think the foundations of unionism have been laid in the packinghouses for a long time to come". Beneath this confident surface, however, there were signs of trouble and future strife. ${ }^{49}$

The union hoped that federal mediation might eventually lead to a contract with the packers. The employers, however, consistently blocked efforts at direct negotiations. They refused to meet with union representatives and even refused to sign arbitration agreements on the same piece of paper. Moreover, not all of Judge Alschuler's subsequent decisions were as favorable to the workers as his first. Additional wage increases were small and failed to keep pace with soaring inflation. Alschuler also rejected demands for union recognition, a shorter work week, double pay for overtime, and the abolition of piece rates in the car shops. Especially disheartening was his response to testimony detailing racial prejudice inside the plants. Having secured a weak commitment from the packers in the first round of hearings not to discriminate, the judge declined to rectify specific instances of inequity in hiring and promotion. ${ }^{50}$

The loyalty of black workers remained indispensable to the ultimate success of the organizing drive. The Labor Council went out of its way to demonstrate its willingness to defend blacks as equals. Officials estimated that a disproportionate forty percent of the SLC's grievances came from black workers. Blacks served alongside whites as stewards and committeemen in most departments, and on a number of occasions the white rank-

${ }^{48}$ Mary McDowell, "Easter Day After the Decision", Survey, XL (13 April 1918), p. 38. Fitzpatrick quoted in Tuttle, Race Riot, pp. 126-127; Barrett, Work and Community, p. 200.

${ }^{49}$ Glatt quoted in 'Tuttle, Race Riot, p. 127; Brody, Butcher Workmen, p. 83; Foster quoted in Johanningsmeier, "William Z. Foster", chapter 5.

${ }_{50}$ Herbst, Negro, pp. 39-40; Brody, Butcher Workmen, p. 84 Barrett, Work and Community, p. 200. "Arbitration of Demands of Employees Filed with the Administrator November 12, 1918", Papers of the United Packinghouse Workers of America, Box 1, Folder 3, State Historical Society of Wisconsin, Madison, WI. 
and-file took action to support their black co-workers. Unprecedented steps towards social equality were taken as well. At a union sponsored ball, two thousand blacks and whites mingled freely, although no mixed couples appeared on the floor. Interracial picnics and social affairs similarly flouted the established racial mores of the period. ${ }^{51}$

Little is known about black union supporters in this period. As indicated above, most of the blacks who enrolled in the union were northerners who had been in the packinghouses for several years. James Barrett has argued convincingly that Local 651 served as a focal point of activity for these unionists. It played an active role in the organizing drive, established a grocery cooperative, sponsored meetings with white workers, and helped launch the Colored Club of the Cook County Labor Party. Yet, the local was an unstable one, at least in comparison to its Slavic counterparts. Monthly membership fluctuated wildly, peaking at 3,000 but averaging below 1,000 , suggesting that beyond a committed core most members were ambivalent about the union. ${ }^{52}$

On the killing floors and in many of the cellar departments where blacks were concentrated, rank-and-file leaders emerged. Yet, one must be careful in drawing inferences from the shop-floor presence of black stewards. In some plants, generally the larger better-organized ones, white-dominated gangs elected blacks to lead them. On the beef kill at Wilson and Company, for instance, black unionists Frank Custer and Robert Bedford shared the stewards' responsibilities with two whites. Any one of the four men was empowered to represent the gang. But in other cases, rather than signifying interracial solidarity, black stewards represented an accommodation to Jim Crow. On the killing floor at G.H. Hammond, black stewards dealt only with black workers and their grievances. Walter Gorniak, the Polish steward admitted, "I don't have anything to do with the colored men". ${ }^{53}$

Among their own race, black unionists were a minority. Their efforts to enroll their brothers and sisters often met with scorn and ridicule. "You are nothing but a lot of white folks' niggers, or you wouldn't be wearing that button", taunted one holdout. While whites returned from work each day to a community that was supportive of their cause and lived amongst fellow unionists, residential segregation meant that black workers were surrounded by people who shared neither their values nor their commitment to unionism as a vehicle for advancement. Their efforts to promote a class

${ }^{51}$ Chicago Commission on Race Relations, Negro in Chicago, pp. 428-429; Spero and Harris, Black Worker, p. 274; Barrett, Work and Community, p. 205. For interracial activity see Sandburg, Chicago Race Riots, p. 55; and Browder, "Some Experiences", p. 35, passim.

${ }_{52}$ Barrett, Work and Community, p. 209; Grossman, “Dream Deferred”, p. 321.

${ }^{53}$ Testimony of Robert Bedford, Frank Custer, Walter Gorniak, Alschuler Hearings; Gorniak quoted, p. 525. 
solidarity that crossed racial lines were often rejected outright or misunderstood as toadying up to whites. Journeying to work, black unionists encountered verbal harassment on the streetcars, and once in the plant had to contend with threats and intimidation. Foremen openly discriminated against black unionists, passing them up for promotion or refusing to let them work if they were late in reporting. Opposed by their own race, never fully accepted by white unionists, and targeted for reprisal by employers, black unionists occupied a precarious and uncomfortable position. ${ }^{54}$

Conflicting loyalties to race and class pulled black packinghouse workers in different directions. Shared work experience and common grievances pushed them towards an alliance with their white co-workers. Yet, the persistence of racial discrimination and the social dynamics of ghetto life produced a race consciousness that militated against making common cause with whites. The situation was markedly different for white workers. For them, ethnic and class loyalties overlapped and were easily reconciled. Religious and civic leaders tended to support the union drive, as did fraternal orders and recreational clubs. Part of a broad community mobilization, the union drive was embedded in the culture of Packingtown. Rather than weakening the bonds of class loyalty, ethnic identity reinforced it. ${ }^{55}$

Sharp differences between the proletarianization experience of blacks and whites help explain the black migrants' ambiguous response to unionization. In contrast to the experience of many of their white co-workers, the formation of the black industrial working class did not involve the loss of autonomy or deskilling. Compared to sharecropping or dead-end domestic service jobs in southern cities the entry of blacks into northern industries represented a rise in economic status. The migrant's focal point for comparison was the world they left behind. The contrast between conditions in Chicago and those in the South blunted the appeal of unionism: packinghouse jobs were dangerous, dirty, and exploitative, but they nonetheless offered both respectable wages and the possibility of advancement. ${ }^{56}$

Aware of the union's strength among whites, the packers regarded the black workforce as the weak link in labor's armor. When the war ended, Judge Alschuler's authority would expire and the struggle between labor and capital would continue without the buffer of arbitration. Whichever side commanded the loyalty of the black workforce would enjoy an incalcu-

${ }^{54}$ Testimony of Robert Bedford and Gus Grabe, Alschuler Hearings; Bedford quoted, p. 221.

${ }_{55}$ For a theoretical discussion of the intermingling of racial and class consciousness, see Joe William Trotter, Jr., Black Milwaukee: The Making of an Industrial Proletariat, 1915-1945 (Urbana, 1984), pp. 276-277.

56 Trotter, Black Milwaukee, p. 277; Dave Roediger, "Movin' On Up to the Midwest's Promised Land", In These Times, 9-15 May 1990, p. 18. 
lable advantage. Accordingly, the packing companies moved to draw blacks into their orbit. Possessing financial resources that dwarfed those of the union, they solidified their ties to the black community. Especially important in this regard were their links to two major ghetto institutions, the Urban League and the Wabash Avenue branch of the Young Mens Christian Association (YMCA).

Founded in 1915, the Chicago branch of the National Urban League quickly became one of the more active chapters in the organization. Responding to the flood of black migrants pouring into the city, the League worked to smooth their transition from the rural South into an urban, industrial environment. It helped secure housing for the newcomers, as well as providing them with social workers and welfare counselors. Its primary function, however, was economic. Seizing upon the opportunity for racial advancement created by the labor shortage, the League worked to convince area industrialists to hire blacks. The organization was successful in this endeavor, placing over 20,000 black men and women in jobs between 1917 and the summer of $1919 . .^{57}$

Although the League valued its independence and sought to assist capital while remaining on friendly terms with labor, its recruitment function and financial dependence upon large corporations placed it firmly on the side of the employers. The League's social workers sought to cultivate model workers by instilling values associated with a capitalist work ethic - efficiency, punctuality, regularity, and thrift. Since the League's reputation depended upon the successful assimilation of black workers into the plants, its Industrial Bureau took great care in recommending for employment only workers that "fit the job" and were not likely to cause trouble. ${ }^{58}$

The Urban League enjoyed a particularly close relationship with the packing companies. Contributions from Armour and Swift helped the League establish itself, and by 1919 a full twenty percent of its annual budget came from the packers' Stockyards Community Clearing House. Although some of the League's staff, including president T. Arnold Hill, privately sanctioned the campaign in the stockyards, the need to please benefactors prevented them from publicly expressing support. Other staff members, most notably Industrial Secretary William Evans, were implacable foes of unionism. Although one should bear in mind Barrett's caveat

${ }^{57}$ In the summer of 1919 the League took over the operation of the US Employment Service's Black Belt office - in itself a measure of the League's importance to both the black community and Chicago's industries. Arvah Strickland, History of the Chicago Urban League (Urbana, 1966); Tuttle, Race Riot, p. 99; Grossman, "Dream Deferred", pp. $245-246$.

${ }^{58}$ Grossman, "Dream Deferred", p. 275; Preston Smith, "The Chicago Urban League" (Ph.D., University of Massachusetts-Amherst, 1988), pp. 26-31; Strickland, History of the Chicago Urban League, pp. 48-49. 
against the assumption that League policies were determined solely by its relationship to the packers, it is difficult to escape his conclusion that "the packers clearly saw the organization as a way of undermining the unions". ${ }^{9}$

The Southside branch of the YMCA served the packers in a more blatant manner. Established in 1911 as the Jim Crow counterpart to the uptown YMCA, the Wabash Avenue building soon became one of the Black Belt's more important social and cultural institutions. Like the Urban League, the "Y" was heavily financed by Chicago industrialists, including the packing companies. After 1916, this support returned handsome dividends, as the YMCA turned increasingly towards industrial work. While its job placement service was more modest than the League's, it found employment for between fifty and one hundred men each month. Far more important than this service, however, were the joint programs the YMCA sponsored with the packers for their employees. ${ }^{60}$

Many of these programs were recreational, such as the glee club organized through Morris and Company in 1917. The YMCA also sponsored an industrial baseball league in which teams such as the "Armour Premiums", and "Swift Star Lambs" competed. In an era when professional baseball was lily-white, these contests had enormous appeal in the black community. In 1919, the league played a full fifty-six game schedule which attracted over 10,000 fans. In addition to providing an outlet for pent-up energy, these kinds of activities fostered a sense of "plant loyalty" and identification with the employer. For these reasons, the packers boosted the $Y$ among their employees, even allowing a representative of the organization access to the plants in order to enroll members. At Armour, as a way of encouraging participation, blacks received a free membership in the $\mathrm{Y}$ after their first year of service. ${ }^{61}$

The centerpiece of the packers' efforts to use the YMCA as a weapon against the union was the Efficiency Club Program. The brainchild of the Y's executive secretary, A.L. Jackson - a man "intellectually and emotionally sympathetic to the packers and decidedly hostile to the unions". The clubs were organized at the same time as the formation of the SLC. They sponsored a series of lectures and educational forums dealing with such topics as "Electricity in the Yards", and "The progress of the negro in the packing industry". Some evidence suggests that workers received actual training in knife and butchering skills. Club meetings were well attended, with upwards of 250 workers present at each session. Foremen urged

${ }^{59}$ Grossman, "Dream Deferred”, p. 360; Tuttle, Race Riot, p. 148; Barrett, Work and Community, p. 212. Evans' attitude toward unionism is revealed in his article "The Negro in Chicago Industries", Opportunity, 1 (February 1923), pp. 15-17.

${ }^{60}$ Grossman, “Dream Deferred”, pp. 247, 272; Tuttle, Race Riot, p. 101.

${ }^{61}$ Grossman, "Dream Deferred", pp. 273, 335; Tuttle, Race Riot, p. 101; Kate J. Adams, Humanizing a Great Industry (Chicago, 1919), p. 21. 
workers to participate in the clubs; and in some cases, an individual's work rating was upgraded if he did so. The packers claimed that the purpose of the clubs was to instill a sense of responsibility among members, but SLC officials charged that they were stridently anti-union. In testimony before Judge Alschuler, Jack Johnstone was characteristically blunt, stating that workers who attended club meetings were "lectured and taught the thing they have to do is keep out of organized labor". Others complained that the clubs were a kind of company union and were actively engaged in spying. ${ }^{62}$

The Wabash Avenue YMCA also promoted the American Unity Labor Union (AULU), a creation of Richard Parker, a well-known Black Belt publisher and entrepreneur. Advertising himself as "the man who was always with his race right or wrong", Parker attempted to woo black packinghouse workers away from the SLC by appealing to both their sense of racial pride and their suspicion of whites. "Get a square deal with your own race", one of his advertisements proclaimed,

Time has come for Negroes to do now or never. Get together and stick together is the call of the Negro. Like all other races, make your own way; the other races have made unions for themselves. They are not going to give it to you just because you join his union. Make a union of your own race; union is strength.

Yet, Parker's motives and the legitimacy of the AULU were suspect. His activities in 1916 on behalf of the packing companies and steel firms betrayed his motives. Traveling south that year as a labor agent, he later boasted that he had "imported more negroes than any man in Chicago". The AULU's ties with the YMCA raise further doubts about its legitimacy, as does the fact that AULU agents were allowed to recruit inside the packinghouses. The AULU remained active through the early 1920s, suggesting that it was more than just a paper organization. Even if it offered no real competition with the SLC, its presence in the yards confused many workers. "Beware the Stockyards Union", warned a handbill distributed by Parker, "do not join any white man's union". Intentionally or not, these kinds of activities played into the hands of the packers. ${ }^{63}$

The end of the war in November 1918 and the ensuing economic demobilization intensified the contest for the loyalty of black workers. The signing

${ }^{62}$ Barrett, Work and Community, p. 213; Grossman, "Dream Deferred", p. 273, pp. 337-339; Adams, Humanizing, p. 21; Testimony of Frank Custer and J.W. Johnstone, Alschuler Hearings, pp. 267-269, 277, 508-509, 545. Evidence on training of butchers from Spero and Harris, Black Worker, p. 268. See also George Arthur, "The Young Men's Christian Association Movement Among Negroes", Opportunity, 1 (March 1923), pp. 16-18.

${ }_{63}$ Herbst, Negro, p. 35; advertisement quoted in Chicago Commission on Race Relations, Negro in Chicago, p. 423; Tuttle, Race Riot, p. 152; handbill quoted in Spero and Harris, Black Worker, p. 272. 
of the armistice placed the continuation of federal arbitration in doubt. No specific expiration date had been set, but both union leaders and the packers now anticipated the opening of a new stage in the struggle for power.

Peace in Europe rewrote the rules governing black employment in Chicago. Practically overnight, the labor shortage that had opened job opportunities for black men and women became a labor surplus. Orders for meat products fell off and repeated rounds of layoffs swept through the packinghouses. Other areas of potential employment dried up as well. By January 1919, the black employment situation had become desperate. Production remained sluggish, and returning servicemen augmented the continued flow of migrants into the labor pool. One US Employment Service official grimly reported that "for the past few days, there has not been a single vacant job in Chicago for a colored man". In early May, over 10,000 black laborers were searching for work, a figure that represented twenty percent of the city's unskilled unemployed. In the short run, this situation worked in the packers' favor. Keenly aware that their color rendered them the most expendable group of workers, many blacks did not want to jeopardize their already precarious position by unionizing. ${ }^{64}$

Unemployment and uncertainty heightened racial friction. The rise in tension was palpable throughout the city, especially in and around workplaces where blacks and whites competed for increasingly scarce jobs. "The relationship between the two races in certain industries where a large number of Negroes are employed such as the packing houses for instance is becoming increasingly delicate", noted a worried Department of Labor official in a letter to Fitzpatrick. Fistfights broke out almost daily in the charged atmosphere of the stockyards; frequently these altercations escalated into brawls involving bricks, knives, and even guns. In May and June, already frayed nerves were set on edge with reports of race riots which had broken out in Texas, South Carolina, and Washington DC. ${ }^{65}$

The SLC's decision to push forward with an aggressive campaign for 100 percent union membership in June 1919 did little to cool tempers or ameliorate racial antagonism. In fact, it had the opposite effect. A deal struck between the Amalgamated and the packing companies the previous month, however, left the Council's leaders with few other options. Aware of sentiment within the SLC for a showdown, the packers approached Secretary of Labor William Wilson and requested a one-year extension of federal arbitration (and with it the no-strike agreement). Bypassing the

${ }^{64}$ Tuttle, Race Riot, pp. 131-132.

${ }^{65}$ Forrester Washington to John Fitzpatrick, 25 January 1919, Fitzpatrick Papers, Box 25, "Negroes" folder, Chicago Historical Society, Chicago, IL; testimony of Walter Gorniak, Alschuler Hearings, p. 512; Tuttle, Race Riot, pp. 23-30. 
SLC, which had resolved to conduct a referendum on the question of renewal, Wilson drew the Amalgamated into negotiations. Without referring the matter to its rank-and-file, and without consulting the other unions, the Amalgamated signed the accord. Predictably, SLC militants were furious and accused the meat cutters of selling them out. Foster termed the episode "one of the most shameful stories of betrayals in American labor history". ${ }^{66}$

Relations between Chicago AMC leaders and the SLC deteriorated rapidly. Dennis Lane claimed that he could not attend union meetings for fear of bodily harm and charged the SLC with circulating false rumors that he held stock in numerous packing companies. Foster's life was threatened; on one occasion, Johnstone fought off AFL gun thugs trying to seize SLC headquarters. Fitzpatrick's attempts to bring the feuding parties together and preserve unity met with only partial success. He managed to postpone an open break - at least for a few months - but internal strife continued to tear the movement apart. ${ }^{67}$

Given this bitter factionalism, it is remarkable that the union was able to consolidate its position and even make further gains in the early summer of 1919. They key to this growing strength was the power exercised by informal groups of workers within the packinghouses. While their leaders fought amongst themselves, shop-floor committees independent of the official union apparatus repeatedly engaged in job actions designed to force the remaining holdouts into the union.

Typically these actions began on the killing floors, where the perishable nature of the product gave workers additional leverage, and then spread to adjoining departments. Workers were precise in their demands, usually warning management in advance of their actions. At G.H. Hammond, for instance, the hog kill steward had repeatedly demanded that the foreman either discharge the non-union members of the gang or require them to join. When he refused to intercede, the gang stopped work, leaving 100 carcasses hanging from the rail. The stoppage quickly spread to other pork operations, idling 900 workers. On the Wilson beef kill, the following message was posted:

Final Notice. Everyone must have their union button on Thursday morning when they come to work or they cannot work. Today is payday. Go to the hall and get your button tonight. This means everybody.

When the Thursday deadline arrived, the gang began killing and dressing cattle, waiting until the chain was full before downing their tools. ${ }^{68}$

${ }^{66}$ Herbst, Negro, p. 41; Brody, Butcher Workmen, pp. 89-90; Barrett, Work and Community, p. 226; Foster, American Trade Unionism, p. 30.

${ }^{67}$ Lane, “A Brief History", p. 1; Foster, American Trade Unionism, pp. 30-31. 
The committees orchestrating these actions were autonomous bodies. Work gangs elected and recalled their stewards directly. Although some of the more radical union leaders may have helped coordinate activity among different plants, most officials were only dimly aware of the existence of the shop floor organizations. Bound by the arbitration agreement, they could not openly sanction the stoppages. Indeed, they found themselves in the uncomfortable position of having to hasten to the scene and attempt to persuade their members to return to work. For their part, many rank-andfile workers believed that the arbitration agreement was void. John Maldek, a floorsman at Wilson, curtly told Judge Alschuler that "the war is over, we can do as we please". Stewards who admitted to understanding that the agreement had been extended defended the stoppages by referring to the democratic workings of the committees. Joseph Sobyro, a steward on Wilson's loading dock, explained that his power was limited to carrying out group decisions. His gang approached him with their demands and told him to communicate them to the foreman. When Alschuler asked Sobyro why he had not ordered the gang to return to work, he replied, "they all have got as much to say as I have". ${ }^{6}$.

Since most of the holdouts were black, the 100 percent campaign had the unintended consequence of polarizing the races. Evidence suggests that the packing companies manipulated this situation in order to exacerbate this division. Management at Wilson, for example, responded to one stoppage by selecting non-union blacks to take the places of strikers. The company also brought a number of black workers to Chicago from its southern plants and directed them to agitate against the union. ${ }^{70}$

One of these workers, Austin "Heavy" Williams, served as a straw boss on the beef kill and as a leader of the Efficiency Club. According to the department steward, Williams rarely worked. "He stands around and his principle job is when new men are hired to button-hole them and tell them to keep out of the union. His job is going downstairs to the employment office and bringing up men and he brings up all non-union men and keeps the non-union men from joining the union." Williams enjoyed considerable authority. As straw boss, he made job assignments and allowed workers to be relieved for rest breaks. Co-workers charged that in return for small payments, he arranged afternoons off and other favors. A talented speaker,

68 Testimony of Jacob Wurmle and S.C. Caleb, Alschuler Hearings, pp. 6-21; Wilson information drawn from testimony of George Williams, Alschuler Hearings, pp. 39-51; notice quoted on p. 47.

69 Testimony of John Maldek, Alschuler Hearings, pp. 75-79; testimony of Joseph Sobyro, Alschuler Hearings, pp. 110-111; see also testimony of Louis Michora, Alschuler Hearings, pp. 96-100.

${ }^{70}$ Testimony of Robert Bedford, Alschuler Hearings, pp. 182-183; testimony of Frank Custer, Alschuler Hearings, p. 230. 
Williams constantly preached against the union and frequently backed up his beliefs with his powerful fists. He did not act alone. Because of his size and his stature, he was the most visible member of a group of about fifteen southern black anti-union agitators on the killing floor. ${ }^{71}$

Several strikes were called in the spring and summer of 1919 in an effort to neutralize agitators like Williams. Unionists complained that these men received preferential treatment and often employed violence in their campaign against the union. Union members, reported one steward, were "afraid to work when they had their back turned toward [the non-union men], for fear of getting a knife jabbed into them". One man was accused of throwing bricks at a group of Polish workers who were distributing union literature at the plant gate. Another worker, arrested for maiming a black union member with an iron bar, received legal counsel from Wilson and Company's attorney. These activities added fuel to an increasingly volatile situation. ${ }^{2}$

As shop-floor tensions rose, union strategists faced a dilemma. On the one hand, they considered the 100 percent campaign an essential measure. Given the uncertainties of continued arbitration, strong organization seemed the best way to safeguard hard-won gains. Yet on the other hand, that very campaign pitted white and black workers against each other and allowed the employers to exploit the resulting animosities. With no clear solution to the problem, SLC leaders pressed forward while redoubling their efforts to promote racial harmony and understanding.

The highpoint of this program - and, by extension, of the entire union organizing effort - came in early July 1919. In an effort to bring black and white workers in contact with one another, the SLC planned a "giant stockyards celebration" which was to commence with an interracial parade winding its way through the Back-of-the-Yards neighborhood, into the Black Belt, and on to a local playground. The thought of such a public display of solidarity worried the packers, who interceded with the police and succeeded in having the march banned on the grounds that it would provoke racial violence. ${ }^{73}$ Undaunted, the SLC held two separate parades, with black and white marchers joining together at the playground.

Despite the interference, the mood of the marchers was upbeat. The packers' effort to quash the affair sharpened the issues and afforded an opportunity for rebuttal. One prominently displayed placard declared: "The bosses think that because we are of different color and different

71 Testimony of Robert Bedford, Alschuler Hearings, pp. 150-152, 177; testimony of Frank Custer, Alschuler Hearings, pp. 261-263; see also testimony of Austin "Heavy" Williams, Alschuler Hearings, pp. 426-454.

72 Testimony of William Bremmer, Alschuler Hearings, p. 194; Barrett, Work and Community, p. 216; Tuttle, Race Riot, p. 154.

73 Herbst, Negro, p. 42; Grossman, "Dream Deferred", p. 297. 
nationalities that we should fight each other. We are going to fool them and fight for a common cause - a square deal for all." Addressing the assembled crowd of 30,000 , Jack Johnstone reiterated this theme:

It does me good to see such a checkerboard crowd - by that I mean that all of the workers here are not standing apart in groups, one race huddled in one bunch, one nationality in another. You are all standing shoulder to shoulder as men, regardless of whether your face is white or black.

The speakers who followed him to the podium that afternoon returned to this point time and again. Speaking in Polish, John Kilkulski urged racial cooperation and respect. A black organizer, Charles Ford, pointedly remarked "You notice there ain't no Jim Crow cars here today", and went on to outline his hope for a future democracy that drew no color line. ${ }^{74}$

In light of the prevailing racial status quo, this free assembly of thousands of black and white workers was remarkable. Jubilant union leaders believed they had surmounted a major barrier. "If the colored packinghouse worker doesn't come into the union, it isn't the fault of the Stock Yards Labor Council", editorialized the CFL's New Majority. Subsequent events seemed to bear out this confidence, as the buoyant mood generated by the celebration translated into concrete organizational gains among the previously aloof black workforce. When the packing companies responded to these advances by directing their special police to break up crowds in the yards and harass organizers, a strike of 10,000 workers forced the withdrawal of the "Cossack Patrol". For a brief moment, it appeared that Chicago's packinghouse workers were ushering in a new era of interracial unionism. ${ }^{75}$

\section{The Chicago race riot}

As it turned out, this optimism was misplaced. Under normal circumstances, it is conceivable that the racial attitudes and prejudices of the past could have been overcome. But Chicago in the summer of 1919 was one of those places in time when "history came off its leash". ${ }^{76}$ The race riot that broke out on the afternoon of 27 July 1919, extinguished any hope that black and white workers might close ranks behind a common purpose. The orgy of violence not only sealed the fate of the SLC's organizing drive, but also drove a wedge between the races that remained in place until the mid-1930s.

74 All quotations from New Majority, 12 July 1919.

75 New Majority, 12 July 1919, 26 July 1919; Herbst, Negro, p. 43; Kampfert, "History", II, p. 166.

${ }_{76}$ The phrase is borrowed from Czeslaw Milosz, quoted in Todd Gitlin, The Sixties:

Years of Hope, Days of Rage (New York, 1987), p. 3. 
The spark that ignited the riot occurred on the lakefront when a group of blacks attempted to gain access to a beach traditionally reserved for whites. A fight ensued, during which a black boy drowned after being struck by a rock thrown from the shore. As rumors spread through the city, a full-scale race war erupted. When tempers cooled five days later, twenty-three blacks and fifteen whites lay dead. In addition, over 500 other persons suffered serious injuries, and hundreds of homes were burned to the ground. ${ }^{77}$

Although the riot began several miles from the stockyards, much of the violence played itself out in the vicinity of the packing plants. This was largely due to the role played by Irish street gangs who saw the disorder as an opportunity to attack blacks with impunity. An official investigation concluded that without the assaults perpetrated by the gangs, "it is doubtful if the riot would have gone beyond the first clash". Many of these gangs were based in Bridgeport, just east of the stockyards, and seem to have been associated with Ragen's Colts - an "athletic club" sponsored by Democratic alderman Frank Ragen. As black packinghouse workers left work on the 27 th, they were unaware of the disturbances raging in the city. Heading east toward their homes, many of these workers became the riot's first casualties, attacked by the white gangs. Enjoying a certain immunity because of their political connections, gang members roamed the streets of the Southside, pulling blacks from the streetcars and even making occasional forays into the Black Belt itself. A fresh cycle of violence commenced the following morning when black workers attempted to make their way to the yards. ${ }^{78}$

Unlike Bridgeport, Back-of-the-Yards remained relatively calm during the initial stages of the riot. Most of the attacks that occurred here took place at the yard gates, and were committed by Irish gangs from the east. Slavic immigrants did not play a role in the racial violence. In a number of instances, Back-of-the-Yards residents interceded to protect blacks from pursuing mobs. This response can be attributed, at least in part, to the impact of unionization on the community. Since the start of the organizing campaign in 1917, SLC leaders had stressed the need for racial solidarity. Judged by the response of the neighborhood to the riot, this principle appears to have taken hold. ${ }^{79}$

In contrast to the inflammatory rhetoric which filled the English language press, the major Polish newspapers remained sober during the riot. They consistently counseled restraint and caution. Dziennik Zwiazkowy even

7 Detailed descriptions of the riot can be found in Tuttle, Race Riot, pp. 4-10, 32-64; and Chicago Commission on Race Relations, Negro in Chicago, pp. 1-52.

${ }^{78}$ Chicago Commission on Race Relations, Negro in Chicago, p. 11; Barrett, Work and Community, p. 220.

${ }^{79}$ Barrett, Work and Community, pp. 222-223; Herbst, Negro, p. 46. 
ran an article on African American history which concluded by asking rhetorically, "Is it not right they should hate whites?" Glose Rabotnica, a labor paper, reminded readers to keep their sights fixed on their true enemy, the packers, whom they hinted might have provoked the unrest. At a public meeting, Father Louis Grudzinski, a respected parish priest, termed the riot "the black pogrom" and appealed for calm. The Polish National Alliance and settlement house workers likewise labored to forestall bloodshed in the streets of Packingtown. ${ }^{80}$

The most important force working to preserve order was the Stockyards Labor Council. Union leaders recognized how much was at stake. In a plea entitled "For White Men to Read", the New Majority implored union members to use their influence in the community to shield blacks from the frenzy of race prejudice. Portraying the riot as their movement's "acid test", the article explained that a critical juncture had been reached: "Right now it is going to be decided whether the colored workers are to continue to come into the labor movement or whether they are going to feel that they have been abandoned by it and lose confidence in it." This crucial question remained unresolved during the troubled days of early August. Anxious to preserve their strained ties with the black workforce, the SLC took the bold step of holding mass interracial meetings. Later, when it became impossible for blacks to reach the Yards safely, the Council organized relief for them and other victimized families. ${ }^{81}$

These efforts proved insufficient. A week after the start of the riot, a new crisis arose which widened the gulf between black and white packinghouse workers. On 2 August, arsonists torched forty-nine homes in a Lithuanian enclave in Back-of-the-Yards. Although blame later was fixed upon the Irish gangs, rumors that revenge-seeking blacks committed the deed gained quick currency. While some spokesmen pointed out the absurd improbability of blacks sneaking undetected into the area, the moderation that prevailed in the neighborhood evaporated and was replaced with hatred and malice. ${ }^{82}$

Significantly, a new round of racial violence did not take place at this point. Still, the fire soured relations between white and black packinghouse workers. Something of the bitterness that swept the community appeared in a column printed in Narod Polski. Comparing the race riot to anti-semitic pogroms in Europe, the article implicitly sanctioned violent action against Jews and blacks, arguing that both groups were under Communist control. Although extreme, this example testifies to the change in mood and spirit

80 Diennik Zwiazkowy, 29 July 1919, quoted in Pacyga, "Villages", p. 294.

${ }^{81}$ New Majority, 2 August 1919; Herbst, Negro, pp. 46-49; Cayton and Mitchell, Black Workers, p. 249.

${ }^{82}$ Barrett, Work and Community, p. 223; Tuttle, Race Riot, pp. 60-61. 
that occurred after the fire. Observing the growing rancor in the white community, Fitzpatrick lamented that the racial breach had grown "so broad that it is almost impossible now to cement or bridge over" ${ }^{83}$

Up to this point, the packing companies had maintained a low profile. Amidst the turmoil following the fire, however, they saw an opportunity to administer a mortal blow to the union movement. Declining to involve either Judge Alschuler or union representatives, they met secretly with city officials and proposed a plan whereby armed troops would escort black workers into the stockyards. Notified of this scheme less than twenty-four hours before its implementation, union leaders reacted in horror. "You must be insane to attempt such a thing", a delegation charged. "These men will be on the killing floor of the packing plants. They will have cleavers and knives. They know how to use them." 84

The packers were unmoved. Rejecting an SLC alternative which proposed establishing a closed shop and charging the union with responsibility for the conduct of its members, they arranged for the state militia to take up positions within and around the yards. Anxious to avoid a bloodbath, the SLC called its members out on strike. On Thursday morning, 8 August, black workers returned to the yards guarded by machine guns and fixed bayonets. A majority of whites stayed home, heeding the strike call, and thereby forestalling what surely would have been an ugly coda to the recent riot. "We have worked day and night to keep this situation in hand", Fitzpatrick reminded the authorities, "not your police, not your soldiers [...] but the union men and women of the stockyards district" have preserved the peace. This was to be the SLC's last hurrah. Its organizing campaign ground to an abrupt and permanent halt. ${ }^{85}$

The union movement unravelled during the following weeks. Despite public displays of interracial goodwill in the yards, members began to slip away. Local 651 was particularly hard hit; decimated by defections, it was kept alive only by the determined efforts of a handful of black activists. Prior to the riot, their task had been a difficult one; now it became virtually impossible to convince black workers to make common cause with whites. "If a thing can't help you when you need help, why have it?", one man reasoned, giving voice to the sentiments of hundreds of others. Many of the community institutions that previously offered lukewarm support now came out against organized labor. Others that had attempted to remain neutral now discarded their careful balancing act. ${ }^{86}$

${ }^{83}$ Narod Polski quoted in Pacyga, "Villages", p. 299. Fitzpatrick quoted in Brody, Butcher Workmen, p. 87.

${ }^{84}$ Herbst, Negro, p. 47; Spero and Harris, Black Worker, p. 277; Cayton and Mitchell, Black Workers, p. 248; New Majority, 9 August 1919.

${ }_{85}$ Brody, Butcher Workmen, p. 88; New Majority, 16 August 1919; Fitzpatrick quoted in Spero and Harris, Black Worker, p. 277. 
The Amalgamated's decision to pull out of the SLC hastened the demise of the movement. During the period of the riot, relations between SLC leaders and the $\mathrm{AMC}$ had reached the breaking point. Charging that the Council was dominated by self-serving radicals, the Amalgamated set up a rival body and ordered its constituent unions to sever their connections with the SLC. The skilled butchers' locals complied with the directive almost immediately, while the mass units of common laborers remained in the SLC. This split reproduced the ethnic cleavages of the past by arraying skilled English speaking butchers (predominantly Irish and German) against unskilled Slavs (mostly Poles and Lithuanians). ${ }^{87}$

Several factors contributed to this situation. AMC officials had always co-existed uneasily with the radical leaders of the Labor Council. Slow in initially responding to signs of unrest in the yards, the AMC only reluctantly agreed to share responsibility for the campaign with the CFL and the syndicalists operating within it. Since actual leadership rested first with Foster and later with Johnstone and Kilkulski, most packinghouse workers looked to these men for guidance rather than to the AMC's own organizers. Alarmed at the militancy displayed by workers during the 100 percent campaign, and feeling that the radicals had encouraged this aggressiveness, Amalgamated officials felt that the movement was slipping out of their control. Preferring arbitration to confrontation, and wanting to avoid "any ill-timed struggle which ultimately brings disaster", the AMC called an end to its cooperation with the SLC. ${ }^{88}$

The Amalgamated's withdrawal undermined the Stockyards Labor Council. For a short period, the two groups competed with each other while the CFL attempted to work out a compromise between them. This was a confusing period for workers in the yards who only dimly understood the issues underlying the factional fighting. Eventually, the Amalgamated prevailed over its rival - but only after it expelled over 30,000 workers who refused to abandon the SLC, and then enlisted the support of the AFL's national office which threatened to revoke the CFL's charter for failing to respect jurisdictional claims. By then the damage had been done. ${ }^{89}$

The Amalgamated paid dearly for its triumph. Having destroyed the SLC and, in the process, alienated itself from the CFL, the union now faced the daunting task of carrying on the stockyards campaign in isolation from the Chicago labor movement. The goal of 100 percent organization, seemingly

\footnotetext{
${ }^{86}$ Herbst, Negro, pp. 51-52; Grossman, "Dream Deferred”, p. 327.

${ }^{87}$ For the Amalgamated's official position and reasoning, see Lane, "A Brief History", p. 1; Herbst, Negro, pp. 43-44; Kampfert, "History", II, pp. 159, 166-167.

${ }_{88}$ Barrett, Work and Community, p. 225; Brody, Butcher Workmen, pp. 89-90; Lane, "A Brief History", p. 1.

89 Brody, Butcher Workmen, pp. 90-91; Barrett, Work and Community, pp. 228-229; New Majority, 24 January 1920.
} 
within grasp just a few months earlier, was now a practical impossibility. Membership tumbled while the union's treasury emptied at an even faster rate, suggesting a loss of confidence among dues paying members. More ominous was the Amalgamated's inability to organize black workers. An attempt to strengthen Local 651 resulted in a flurry of "hectic impotent activity" but no real gains. By 1921, the Local - still the key to workers' power in the yards - contained only forty-nine paid-up members. ${ }^{90}$

As the Amalgamated disintegrated, the packers went on the offensive. They consolidated their ties to institutions in the black community, took advantage of an economic recession in 1920-1921 by selectively laying off shop-floor leaders, and instituted an ambitious system of employee representation designed to woo workers away from the union. ${ }^{91}$

For two more years, the packing companies and the Amalgamated submitted disputes to arbitration. Judge Alschuler continued to adjudicate these matters, frequently ruling in favor of the union. While this system helped the Amalgamated retain some influence in the packinghouses, it favored the employers in the long run by diluting the union's strength. This was made clear when the packers withdrew from the arbitration agreement in 1921, leaving the AMC without any shop-floor organization to which they could turn.

The final chapter came late in 1921, when the Amalgamated called its members out on strike in response to wage cuts. Lacking a firm base of support in the plants, unable to count on the loyalty of the black workforce, and no longer acting in tandem with the various craft unions in the yards, the Amalgamated was in a vulnerable position. The onset of the winter slack season and widespread unemployment further reduced its chances for success. Despite Dennis Lane's confident claim on the eve of the walkout that "tomorrow morning will see the packing establishments closed tight", the strike was ineffective. Less than a third of the workers heeded the initial strike call. Of the large packers, only Wilson was shut down. ${ }^{22}$

In the days that followed, the ranks of the strikers grew. Key departments in Armour and Swift joined the protest, and the Back-of-the-Yards community closed ranks behind the strikers. Donations of food and funds rolled in, while religious and fraternal organizations voiced their outspoken support. Battles fought between police and crowds estimated at 100,000 result-

90 Barrett, Work and Community, pp. 229-230; Kampfert, "History", II, p. 208; Herbst, Negro, pp. 56-57, 63.

${ }^{91}$ The packers' offensive is detailed in Barrett, Work and Community, pp. 240-254. The packers' welfare capitalism is examined in Rick Halpern, "The Iron Fist and the Velvet Glove: Welfare Capitalism in Chicago's Packinghouses, 1922-1933" Journal of American Studies (forthcoming, 1992).

${ }_{92}$ Brody, Butcher Workmen, pp. 102-104; Lane quoted in New York Times, 6 December 1921; Kampfert, "History", II, p. 199. 
ed in national headlines and the threat of federal troops. Nevertheless, the strike was doomed. Particularly damaging was the decision of the Teamsters and Elevated Engineers to cross the AMC's picket lines. Sweeping court injunctions further hindered the action. ${ }^{93}$

Ultimately, it was the ease with which the packers secured replacement workers that crippled the strike. Unemployment in Chicago reached a five year high in December of 1921, resulting in an ample supply of reserve labor. "Scouts" and "runners" for the packers positioned themselves at railroad stations, elevated platforms, saloons, and pool halls, sending hundreds of recruits to the yards each day. At least half of the strikebreakers were black. This was not an accident but the result of conscious design. As soon as the union issued its strike call, the packers set up an employment office in the heart of the Black Belt and arranged for transportation to and from the stockyards. This local pool was augmented by several thousand black southerners, brought into Chicago aboard special trains which carried them through the gauntlet of angry strikers into the yards. ${ }^{94}$

While some black packinghouse workers stuck with the union, the great majority elected to remain at work during the strike. This decision was a pragmatic one, based on a careful weighing of options. Given the events of 1919 and the spotty record of the Amalgamated, the jobs offered by the packers were more important than any potential benefits the union hoped to provide. For many other black workers with no previous experience in the packing industry, the strike was an opportunity for economic advancement. Even after the wage cuts, packinghouse employment paid far more than other available jobs. Moreover, the community's leading institutions lined up with the packers. "Self-preservation is the first law of nature", declared the Defender, a theme echoed by the Urban League which enthusiastically carried on its placement work during the strike. The black churches actively opposed the "white man's union" as well. On the Sunday before the strike, union representatives attended the fifteen most influential black churches. In all but one of these, ministers read a communication from the packers urging workers to disregard the strike. Several days later, when a black AMC organizer attempted to present an appeal to these same pastors, he was told they were attending a meeting called by Armour \& Company. ${ }^{95}$

By Christmas, the mood in Packingtown was one of grim desperation.

${ }^{93}$ Barrett, Work and Community, pp. 258-260; Kampfert, "History", II, pp. 200-211; New York Times, 8 and 9 December 1921.

94 New York Times, 29 December 1921; Herbst, Negro, pp. 63-65; Cayton and Mitchell, Black Workers, pp. 255-256.

${ }^{95}$ Defender quoted in Spero and Harris, Black Worker, p. 281; William Evans, "The Negro in Chicago Industries", Opportunity, 1 (February 1923); and Strickland, "History", p. 73. Herbst, Negro, pp. 64-65. 
The smoke bellowing from the plants testified to the strike's waning strength. The Amalgamated began putting out peace feelers, sensing the futility of prolonging of the conflict. When the packers stonewalled, the only remaining possibility for a settlement lay in federal mediation. In January, however, representatives of the Department of Labor visited the Amalgamated's headquarters and advised the union to abandon hope for intervention. By the time the AMC's Executive Board met and conceded defeat, the strike had been dead for weeks and the packing plants were operating as open shops. ${ }^{96}$

In many ways, the true moment of defeat had occurred two years earlier when the race riot alienated the majority of black workers and the destruction of the Stockyards Labor Council fragmented the white labor movement. Rather than representing the climax to the organizing drive that began in 1917, the 1921 strike is best regarded as its brief epilogue. The strike defeat hardened racial attitudes for many years. Only in the mid-1930s, with the emergence of the Congress of Industrial Organizations (CIO), did black and white workers again take steps in the direction of solidarity. When that process began, the events of 1917-1921 loomed large in workers' memories and imaginations. A major lesson emerged: the overriding need for interracial solidarity. Regardless of their racial attitudes or inherited prejudices, workers realized that a divided movement stood little chance of success against the power and resources of the packers. Gertie Kamarcyk explained, there was "a kind of feeling that we just had to work together [...] or the bosses were just gonna let us have it in the neck again". Others expressed similar sentiments. Joe Zabritski recalled that the old-timers resigned themselves to including blacks in the new campaign. "They didn't come in and hug 'em and kiss 'em", he quickly admitted. "But they knew they had to be together, period. Even though some of them were anti-negro, they still knew you had to be together to form a union and to win some of their demands". Thus, while the defeat of the AMC resulted in a legacy of fear and distrust, it also spelled the end of exclusionary, craft-based unionism in the stockyards. ${ }^{97}$

96 Brody, Butcher Workmen, p. 105; New York Times, 25 December 1921, 1 January 1922, 1 February 1922.

${ }^{97}$ Interview with Gertie Kamarczyk, 5 December 1987; interview with Joe Zabritski, 4 December 1987, both in possession of the author. 